\title{
Mycoplasma elephantis sp. nov., a New Species from Elephants
}

\author{
HELGA KIRCHHOFF, ${ }^{1 *}$ ROSEMARIE SCHMIDT, ${ }^{1}$ HEINER LEHMANN, ${ }^{2}$ \\ HAROLD W. CLARK, ${ }^{3}$ AND AURIOL C. HILL ${ }^{4}$ \\ Institut für Mikrobiologie und Tierseuchen, Tierärztliche Hochschule Hannover, 30173 Hannover, ${ }^{1}$ and Botanisches Institut, \\ Tierärztliche Hochschule Hannover, 30559 Hannover, ${ }^{2}$ Germany; Mycoplasma Research Institute, Beverly Hills, Florida $32665^{3}$; \\ and Medical Research Council Toxicology Unit, Carshalton, Surrey SM5 4EF, United Kingdom ${ }^{4}$
}

\begin{abstract}
Organisms with the typical characteristics of mycoplasmas were isolated from the genital tracts of female elephants. The results of growth inhibition tests, metabolic inhibition tests, indirect immunofluorescence tests, and immunobinding assays showed that the isolated mycoplasmas were identical and distinct from previously described Mycoplasma, Entomoplasma, Mesoplasma, and Acholeplasma species. These organisms represent a new species, for which the name Mycoplasma elephantis is proposed. M. elephantis ferments glucose, fructose, maltose, mannose, and sucrose, produces films and spots, does not hydrolyze arginine, esculin, and urea, does not reduce methylene blue, tetrazolium chloride, and potassium tellurite, does not possess phosphatase activity, and reduces resazurin. It lyses avian, ovine, and guinea pig erythrocytes. It does not adsorb erythrocytes. Cholesterol or serum is required for growth. The optimum growth temperature is $37^{\circ} \mathrm{C}$. The $\mathrm{G}+\mathrm{C}$ content of the DNA is $24.0 \mathrm{~mol} \%$. The type strain of $M$. elephantis is E42 (= ATCC 51980).
\end{abstract}

During a survey of arthritic elephants in circuses and zoos, mycoplasmas were isolated from the genital organs of about $60 \%$ of the female animals. The elephants investigated belonged to the species Elephas maximus and Loxodonta africana. Mycoplasmas were obtained by swabbing vaginas and urethras $(3,4)$. In this study two of the mycoplasma strains isolated, strains $\mathrm{E} 42^{\mathrm{T}}(\mathrm{T}=$ type strain) and $\mathrm{E} 73$, were characterized and compared with previously described Mycoplasma, Entomoplasma, Mesoplasma, and Acholeplasma species.

\section{MATERIALS AND METHODS}

Cultivation of mycoplasmas. Mycoplasmas were cultivated in a medium described previously $(10,24)$ or in medium containing $19 \mathrm{~g}$ of heart infusion broth (or $30 \mathrm{~g}$ of heart infusion agar [Difco Laboratories, Detroit, Mich.] for solid medium), $5 \mathrm{~g}$ of yeast extract (Oxoid, Ltd., London, United Kingdom), $200 \mathrm{ml}$ of heat-inactivated $\left(56^{\circ} \mathrm{C}, 30 \mathrm{~min}\right)$ horse serum, $10^{6} \mathrm{IU}$ of penicillin, and $800 \mathrm{ml}$ of distilled water. Subcultivation on solid medium was done after incubation for 3 to 5 days at $37^{\circ} \mathrm{C}$ under aerobic or anaerobic (GasPak System; Oxoid, Ltd.) conditions. Mycoplasmas were filter cloned five times by using 220-nm-pore-size filters (21).

Morphological studies. The colonies of the mycoplasmas were examined with a stereomicroscope (Leitz). The cellular morphology of the organisms was assessed by dark-field microscopy and transmission electron microscopy of sectioned organisms. Ultrathin sections of organisms were prepared as described previously (12).

Filtration studies. Cultures (after $24 \mathrm{~h}$ of incubation) were diluted 1:10 in liquid medium and filtered through membrane filters (Millipore Corp., Bedford, Mass.) with pore diameters of 220 and $300 \mathrm{~nm}$. The numbers of CFU per milliliter in the filtrates were determined by plating the filtrates onto agar and were compared with the number of CFU per milliliter in an unfiltered culture dilution.

Reversion experiments. The organisms were subcultured five times by using liquid or solid medium lacking penicillin or thallium acetate and were incubated aerobically at $37^{\circ} \mathrm{C}$. Agar plates and fluid cultures were examined for alterations in the morphology of colonies and cells, respectively.

Sterol dependence. Single colonies of strains $\mathrm{E} 42^{\mathrm{T}}$ and $\mathrm{E} 73$ were seeded onto serum-free solid media supplemented with $0.5 \%$ bovine serum albumin, $0.5 \%$ glucose, and $10 \mu \mathrm{g}$ of palmitic acid per ml. Cholesterol, dissolved in Tween 80 , was added to final concentrations of $20,10,5$, and $1 \mu \mathrm{g} / \mathrm{ml}$. Plates containing no cholesterol were included $(7,18)$. The mycoplasmas were also subcultured on basal agar medium without serum.

Strains $\mathrm{E} 42^{\mathrm{T}}$ and $\mathrm{E} 73$ were also tested indirectly for sterol dependence by a paper disk inhibition method (8), in which we used either dried disks that

* Corresponding author. Mailing address: Tierärztliche Hochschule Hannover, Bischofsholer Damm 15, 30173 Hannover, Germany. Phone: (049)-511-856-7595. Fax: (049)-511-856-7697. originally contained $0.02 \mathrm{ml}$ of a $1.5 \%$ (wt/vol) ethanolic solution of digitonin (Sigma Chemical Co., St. Louis, Mo.) or wet disks containing $0.02 \mathrm{ml}$ of a $20 \%$ (wt/vol) aqueous solution of sodium polyanethol sulfonate (Koch-Light Laboratories Ltd., Colnbrook, England). The widths of zones of growth inhibition were measured in millimeters.

Biochemical activity. Strains E42 $2^{\mathrm{T}}$ and E73 were examined for metabolism of glucose, fructose, maltose, mannose and sucrose; for hydrolysis of esculin, arginine ( 1 and $0.1 \%$ ), and urea; for reduction of methylene blue, resazurin, tetrazolium chloride, and potassium tellurite; and for phosphatase activity. Film and spot production was tested on $10 \%$ egg yolk agar $(1,2,25)$. Positive and negative controls were used for all tests. All negative tests were checked for viability of the organisms.

Hemolysis and hemadsorption. Strains $E 42^{\mathrm{T}}$ and $\mathrm{E} 73$ were examined for hemolytic activity and hemadsorption by using chick, guinea pig, and sheep erythrocytes $(1,14)$.

SDS-PAGE and Western blotting (immunoblotting). The procedures which we used for sodium dodecylsulfate-polyacrylamide gel electrophoresis (SDSPAGE) and Western blotting have been described in detail previously (19). Blots were treated with rabbit antisera (Table 1) diluted 1:1,000 as the primary antibodies and with peroxidase-conjugated goat antiserum to rabbit immunoglobulins (Nordic, Tilburg, The Netherlands) diluted 1:1,000 as the secondary antibody and were developed with a solution containing $12 \mathrm{mg}$ of 4-chlor-1-naphtol (AIdrich, Steinheim, Germany), $4 \mathrm{ml}$ of methanol, $20 \mu \mathrm{l}$ of $\mathrm{H}_{2} \mathrm{O}_{2}(30 \%)$, and $20 \mathrm{ml}$ of phosphate-buffered saline.

DNA base composition. DNA was extracted from centrifuged broth culture deposits of strain $\mathrm{E} 42^{\mathrm{T}}$ by using the method of Gross-Bellard et al. (9), and the guanine-plus-cytosine $(\mathrm{G}+\mathrm{C})$ content was determined from the buoyant density of the DNA in cesium chloride by ultracentrifugation (20). DNA extracted from Escherichia coli with a known $\mathrm{G}+\mathrm{C}$ content was included as a control.

Serological studies. Antisera were prepared as described by Morton and Roberts (15). A serological comparison of strains $E 42^{\mathrm{T}}$ and $\mathrm{E} 73$ with each other and with members of previously described Mollicutes species was performed by using growth inhibition tests $(5)$, metabolism inhibition tests in microtiter plates $(11,17,23)$, indirect immunofluorescence tests $(6)$, and immunobinding assays with unfixed colonies on agar blocks (16) or with colonies transferred to nitrocellulose (13). Tests with strains E42 ${ }^{\mathrm{T}}$ and E73 were done in two directions; i.e., reference antisera were tested with strains $\mathrm{E} 42^{\mathrm{T}}$ and $\mathrm{E} 73$, and antisera against $E 42^{\mathrm{T}}$ and $\mathrm{E} 73$ were tested with the type strains of previously described mycoplasmas. The antisera and type strains used for serological investigations are listed in Table 1.

\section{RESULTS AND DISCUSSION}

Morphology and ultrastructure. Colonies of strains $E 42^{\mathrm{T}}$ and E73 were visible on agar medium after 2 to 3 days of incubation under aerobic and anaerobic conditions, although during primary isolation the strains grew better in an anarobic environment $(3,4)$. The colonies had a typical fried-egg appearance (Fig. 1A). Pleomorphic cells were observed in broth cultures by dark-field microscopy and after staining by the 
TABLE 1. Mycoplasma, Entomoplasma, Mesoplasma, and Acholeplasma strains and antisera used in comparative serological tests with the elephant mycoplasmas

\begin{tabular}{|c|c|c|}
\hline \multirow{2}{*}{ Strain } & \multicolumn{2}{|c|}{ Source $(\mathrm{s})^{a}$} \\
\hline & Mycoplasmas & Antisera \\
\hline Mycoplasma adleri $\mathrm{G}-145^{\mathrm{T}}$ & FCR & FCR \\
\hline M. agalactiae $\mathrm{PG} 2^{\mathrm{T}}$ & IRC & IRC \\
\hline M. alkalescens $\mathrm{D} 12^{\mathrm{T}}$ & NIH & $\mathrm{NIH}$ \\
\hline M. alvi Ilsley ${ }^{\mathrm{T}}$ & IRC & IRC \\
\hline M. anatis $1340^{\mathrm{T}}$ & $\mathrm{NIH}$ & NIH, IMT \\
\hline M. anseris $1219^{\mathbf{T}}$ & VMR & VMR \\
\hline M. arginini $\mathrm{G} 230^{\mathrm{T}}$ & $\mathrm{NIH}$ & NIH, IMT \\
\hline M. arthritidis $\mathrm{PG}^{\mathrm{T}}$ & NIH & NIH, IMT \\
\hline M. auris $\mathrm{U} \mathrm{A}^{\mathrm{T}}$ & FCR & FCR \\
\hline M. bovigenitalium $\mathrm{PG}_{11}{ }^{\mathrm{T}}$ & $\mathrm{NIH}$ & NIH, IMT \\
\hline M. bovirhinis $\mathrm{PG}_{4} 3^{\mathrm{T}}$ & NIH & NIH, IMT \\
\hline$M$. bovis Donetta ${ }^{\mathrm{T}}$ & IRC & IRC, IMT \\
\hline M. bovoculi M165/69 & IRC & IRC \\
\hline M. buccale $\mathrm{CH} 20247^{\mathrm{T}}$ & $\mathrm{NIH}$ & $\mathrm{NIH}$ \\
\hline M. buteonis $\mathrm{Bb} / \mathrm{T} 2 \mathrm{~g}^{\mathrm{T}}$ & $\mathrm{JMT}$ & IMT \\
\hline M. californicum ST6 ${ }^{\mathrm{T}}$ & IRC & IRC \\
\hline$M$. canadense $275 \mathrm{C}^{\mathrm{T}}$ & IRC & IRC, IMT \\
\hline M. canis $\mathrm{PG} 14^{\mathrm{T}}$ & NIH & NIH, IMT \\
\hline M. capricolum subsp. capricolum California $\mathrm{Kid}^{\mathrm{T}}$ & IRC & IRC \\
\hline M. capricolum subsp. capripneumoniae $\mathrm{F} 38^{\mathrm{T}}$ & IRC & IRC \\
\hline M. caviae $\mathrm{G} 122^{\mathrm{T}}$ & IRC & NIH, IMT \\
\hline M. cavipharyngis $117 \mathrm{C}^{\mathrm{T}}$ & FCR & FCR \\
\hline M. citelli $\mathrm{RG}-2 \mathrm{C}^{\mathrm{T}}$ & IRC & IRC \\
\hline M. cloacale $383^{\mathrm{T}}$ & FCR & FCR \\
\hline M. collis $58 \mathrm{~B}^{\mathrm{T}}$ & FCR & FCR \\
\hline M. columbinasale $694^{\mathrm{T}}$ & IRC & IRC \\
\hline M. columbinum MMP-1 ${ }^{\mathrm{T}}$ & IRC & IRC \\
\hline M. columborale MMP-4 $4^{\mathrm{T}}$ & IRC & IRC \\
\hline M. conjunctivae $\mathrm{HRC} 581^{\mathrm{T}}$ & IRC & NIH, IMT \\
\hline M. corogypsi $\mathrm{BV}^{\mathrm{T}}$ & FCR & IMT, FCR \\
\hline M. cottewii $\mathrm{VIS}^{\mathrm{T}}$ & FCR & FCR \\
\hline M. cricetuli $\mathrm{CH}^{\mathrm{T}}$ & FCR & FCR \\
\hline M. cynos $\mathrm{H} 831^{\mathrm{T}}$ & IRC & IRC, IMT \\
\hline$M$. dispar $462 / 2^{\mathrm{T}}$ & IRC & IRC, IMT \\
\hline M. edwardii $\mathrm{PG} 24^{\mathrm{T}}$ & IRC & IRC, IMT \\
\hline M. equigenitalium $\mathrm{T} 37^{\mathrm{T}}$ & IMT & IMT \\
\hline M. equirhinis $\mathrm{M} 432 / 72^{\mathrm{T}}$ & LIRA & LIRA, IMT \\
\hline M. falconis $\mathrm{H} / \mathrm{T} 1^{\mathrm{T}}$ & IMT & IMT \\
\hline M. fastidiosum $4822^{\mathrm{T}}$ & IRC & IRC \\
\hline M. faucium $\mathrm{DC} 333^{\mathrm{T}}$ & NIH & NIH \\
\hline M. felifaucium $\mathrm{PU}^{\mathrm{T}}$ & MRC & MRC \\
\hline M. feliminutum $\mathrm{Ben}^{\mathrm{T}}$ & IRC & IRC \\
\hline M. felis $\mathrm{CO}^{\mathrm{T}}$ & IRC & NIH, IMT \\
\hline M. fermentans $\mathrm{PG} 18^{\mathrm{T}}$ & $\mathrm{NIH}$ & NIH, IMT \\
\hline M. flocculare $\mathrm{Ms} 42^{\mathrm{T}}$ & SVS & SVS \\
\hline$M$. gallinaceum $\mathrm{DD}^{\mathrm{T}}$ & $\mathrm{NIH}$ & NIH, IMT \\
\hline M. gallinarum $\mathrm{PG} 16^{\mathrm{T}}$ & NIH & $\mathrm{NIH}$ \\
\hline M. gallisepticum $\mathrm{PG} 1^{\mathrm{T}}$ & $\mathrm{NIH}$ & NIH, IMT \\
\hline M. gallopavonis WR $1^{\mathrm{T}}$ & IRC & IRC \\
\hline M. gateae $\mathrm{CS}^{\mathrm{T}}$ & IRC & IRC, IMT \\
\hline M. genitalium $\mathrm{G} 37^{\mathrm{T}}$ & FCR & FCR \\
\hline M. glycophilum $486^{\mathrm{T}}$ & FCR & FCR \\
\hline M. gypis $\mathrm{B} 1 / \mathrm{T} 1^{\mathrm{T}}$ & IMT & IMT \\
\hline M. hominis $\mathrm{PG} 21^{\mathrm{T}}$ & NIH & NIH \\
\hline M. hyopharyngis $\mathrm{H} 3-6 \mathrm{BF}^{\mathrm{T}}$ & FCR & FCR \\
\hline M. hyopneumoniae $\mathrm{J}^{\mathrm{T}}$ & SVS & SVS, IMT \\
\hline M. hyorhinis $\mathrm{BTS}^{\mathrm{T}}$ & NIH & NIH, CVM \\
\hline M. hyosynoviae $\mathrm{S} 16^{\mathrm{T}}$ & CVM & CVM, IMT \\
\hline M. imitans $4229^{\mathrm{T}}$ & FCR & FCR \\
\hline$M$. indiense $3 \mathrm{~T}^{\mathrm{T}}$ & FCR & FCR \\
\hline M. iners $\mathrm{PG} 30^{\mathrm{T}}$ & $\mathrm{NIH}$ & NIH \\
\hline M. iowae $695^{\mathrm{T}}$ & IRC & IRC \\
\hline M. leocaptivus $3 \mathrm{~L} 2^{\mathrm{T}}$ & NCTC, FCR & NCTC, FCR \\
\hline M. leopharyngis $\mathrm{LL} 2^{\mathrm{T}}$ & NCTC, FCR & NCTC, FCR \\
\hline M. lipofaciens $\mathrm{R} 171^{\mathrm{T}}$ & FCR & FCR \\
\hline M. lipophilum $\mathrm{MaBy}^{\mathrm{T}}$ & $\mathrm{NIH}$ & NIH \\
\hline M. maculosum $\mathrm{PG}^{\mathrm{T}} \mathrm{T}^{\mathrm{T}}$ & $\mathrm{NIH}$ & NIH \\
\hline M. meleagridis $17529^{\mathrm{T}}$ & IRC & IRC \\
\hline M. moatsii $\mathrm{MK} 405^{\mathrm{T}}$ & IRC & IRC, IMT \\
\hline
\end{tabular}

TABLE 1-Continued

\begin{tabular}{|c|c|c|}
\hline \multirow{2}{*}{ Strain } & \multicolumn{2}{|c|}{ Source(s) ${ }^{a}$} \\
\hline & Mycoplasmas & Antisera \\
\hline M. mobile $163 \mathrm{~K}^{\mathrm{T}}$ & IMT & IMT \\
\hline M. molare $\mathrm{H} 542^{\mathrm{T}}$ & IRC & IRC, IMT \\
\hline M. muris RIII4 ${ }^{\mathrm{T}}$ & FCR & FCR \\
\hline M. mustelae $\mathrm{MX9}^{\mathrm{T}}$ & FCR & FCR \\
\hline M. mycoides subsp. mycoides $\mathrm{PG} 1^{\mathrm{T}}$ & IRC & IRC \\
\hline M. mycoides subsp. capri $\mathrm{PG}^{\mathrm{T}}$ & IRC & IRC \\
\hline$M$. neurolyticum type $\mathrm{A}^{\mathrm{T}}$ & NIH & NIH, IMT \\
\hline M. opalescens MH5408 ${ }^{\mathrm{T}}$ & IRC & IRC, IMT \\
\hline M. orale $\mathrm{CH} 19299^{\mathrm{T}}$ & NIH & NIH \\
\hline M. ovipneumoniae $\mathrm{Y} 98^{\mathrm{T}}$ & IRC & IRC, IMT \\
\hline M. oxoniensis $128^{\mathrm{T}}$ & FCR & FCR \\
\hline M. penetrans GTU54 ${ }^{\mathrm{T}}$ & FCR & FCR \\
\hline M. phocacerebrale $1049^{\mathrm{T}}$ & IMT & IMT \\
\hline M. phocarhinis $852^{\mathrm{T}}$ & IMT & IMT \\
\hline M. phocidae $105^{\mathrm{T}}$ & MAFC & MAFC \\
\hline M. pirum $\mathrm{HRC} 70-159^{\mathrm{T}}$ & FCR & FCR \\
\hline M. pneumoniae $\mathrm{FH}^{\mathrm{T}}$ & NIH & NIH, IMT \\
\hline M. primatum $\mathrm{HRC} 292^{\mathrm{T}}$ & $\mathrm{NIH}$ & $\mathrm{NIH}$ \\
\hline M. pullorum $\mathrm{CKK}^{\mathrm{T}}$ & IRC & IRC \\
\hline M. pulmonis $\mathrm{PG} 34^{\mathrm{T}}$ & $\mathrm{NIH}$ & NIH, IMT \\
\hline M. putrefaciens $\mathrm{KS}-1^{\mathrm{T}}$ & IRC & IRC, IMT \\
\hline$M$. salivarium $\mathrm{PG} 20^{\mathrm{T}}$ & $\mathrm{NIH}$ & $\mathrm{NIH}$ \\
\hline$M$. simbae $\mathrm{LX}^{\mathbf{T}}$ & NCTC, FCR & NCTC, FCR \\
\hline M. spermatophilum AH $159^{\mathrm{T}}$ & FCR & FCR \\
\hline M. spumans $\mathrm{PG} 13^{\mathrm{T}}$ & $\mathrm{NIH}$ & NIH, IMT \\
\hline M. sualvi Mayfield $\mathbf{B}^{\mathrm{T}}$ & GIRA & GIRA \\
\hline M. subdolum TB $^{\mathrm{T}}$ & IMT & $\mathrm{IMT}$ \\
\hline M. synoviae WVU $1853^{\mathrm{T}}$ & IRC & IRC \\
\hline M. testudinis $01008^{\mathrm{T}}$ & MRC & MRC \\
\hline M. verecundum $107^{\mathrm{T}}$ & IRC & IRC, IMT \\
\hline M. yeatsii $\mathrm{GIH}^{\mathrm{T}}$ & FCR & FCR \\
\hline Entomoplasma ellychniae ELCN-1 ${ }^{\mathrm{T}}$ & FCR & FCR \\
\hline E. hucivorax PIPN-2 ${ }^{\mathrm{T}}$ & FCR & FCR \\
\hline E. luminosum PIMN-1 ${ }^{\mathrm{T}}$ & FCR & FCR \\
\hline E. melaleucae $\mathrm{M}^{\mathrm{T}}$ & FCR & FCR \\
\hline E. somnilux PYAN-1 ${ }^{\mathbf{T}}$ & FCR & FCR \\
\hline Mesoplasma entomophilum $\mathrm{TAC}^{\mathrm{T}}$ & FCR & FCR \\
\hline M. florum $\mathbf{L} 1^{\mathbf{T}}$ & FCR & FCR \\
\hline M. lactucae $831-\mathrm{C}^{\mathrm{T}}$ & FCR & FCR \\
\hline M. seifferti $\mathrm{F} 7^{\mathrm{T}}$ & FCR & FCR \\
\hline Acholeplasma axanthum S-743 & IRC & IRC, IMT \\
\hline A. cavigenitalium $\mathrm{GP}^{\mathrm{T}}$ & FCR & FCR \\
\hline A. equifetale $\mathrm{C} 112^{\mathrm{T}}$ & IMT & IMT \\
\hline A. granularum BTS39 & NIH & NIH, IMT \\
\hline A. hippikon $\mathrm{C}^{\mathrm{T}}$ & IMT & IMT \\
\hline A. laidlawii $\mathrm{PG} 8^{\mathrm{T}}$ & NIH & NIH, IMT \\
\hline A. modicum $\mathrm{PG} 49^{\mathrm{T}}$ & IRC & IRC, IMT \\
\hline A. morum $72-43^{\mathrm{T}}$ & FCR & FCR \\
\hline A. multilocale $\mathrm{PN} 525^{\mathrm{T}}$ & MRC & MRC \\
\hline A. oculi $19 \mathrm{~L}^{\mathrm{T}}$ & IRC & IRC, IMT \\
\hline A. parvum $\mathrm{H}_{2} 3 \mathrm{M}^{\mathrm{T}}$ & FCR, VFV & FCR, VFV \\
\hline Bovine serogroup strain 7PG50 & IRC & IRC \\
\hline
\end{tabular}

${ }^{a}$ Abbreviations: ATCC, American Type Culture Collection, Rockville, Md.; CVM, R. F. Ross, College of Veterinary Medicine, Iowa State University, Ames; FCR, J. G. Tully, Mycoplasma Section, Frederick Cancer Research Facility, Frederick, Md.; GIRA, R. M. Gourlay, Institute for Research on Animal Diseases, Compton, Newbury, Berkshire, England; IMT, H. Kirchhoff, Institut für Mikrobiologie und Tierseuchen, Tierärztliche Hochschule Hannover, Hannover, Germany; IRC, E. A. Freundt, Food and Agriculture Organization, World Health Organization, International Reference Centre for Animal Mycoplasmas, Aarhus Denmark; LIRA, R. Lemcke, Institute for Research of Animal Diseases, Compton, Newbury, Berkshire, England; MAFC, H. L. Ruhnke, Ministry of Agriculture and Food, Veterinary Laboratory Services, Guelph, Ontario, Canada; MRC, A. Hill, Medical Research Council Laboratories, Carshalton, Surrey, England; NCTC, National Collection of Type Cultures, London, England; NIH, M. F. Barile and J. G. Tully, National Institutes of Health, Bethesda, Md.; SVS, N. F. Friis, Statens Veterinaere Serum Laboratorium, Copenhagen, Denmark; VFV, M. Ogata, Department of Veterinary Public Health, Azabu University, Fuchinobe Sagamihara, Kanagawa, Japan; VMR, L. Stipkovits, Veterinary Medical Research Institute, Hungarian Academy of Science, Budapest, Hungary. 

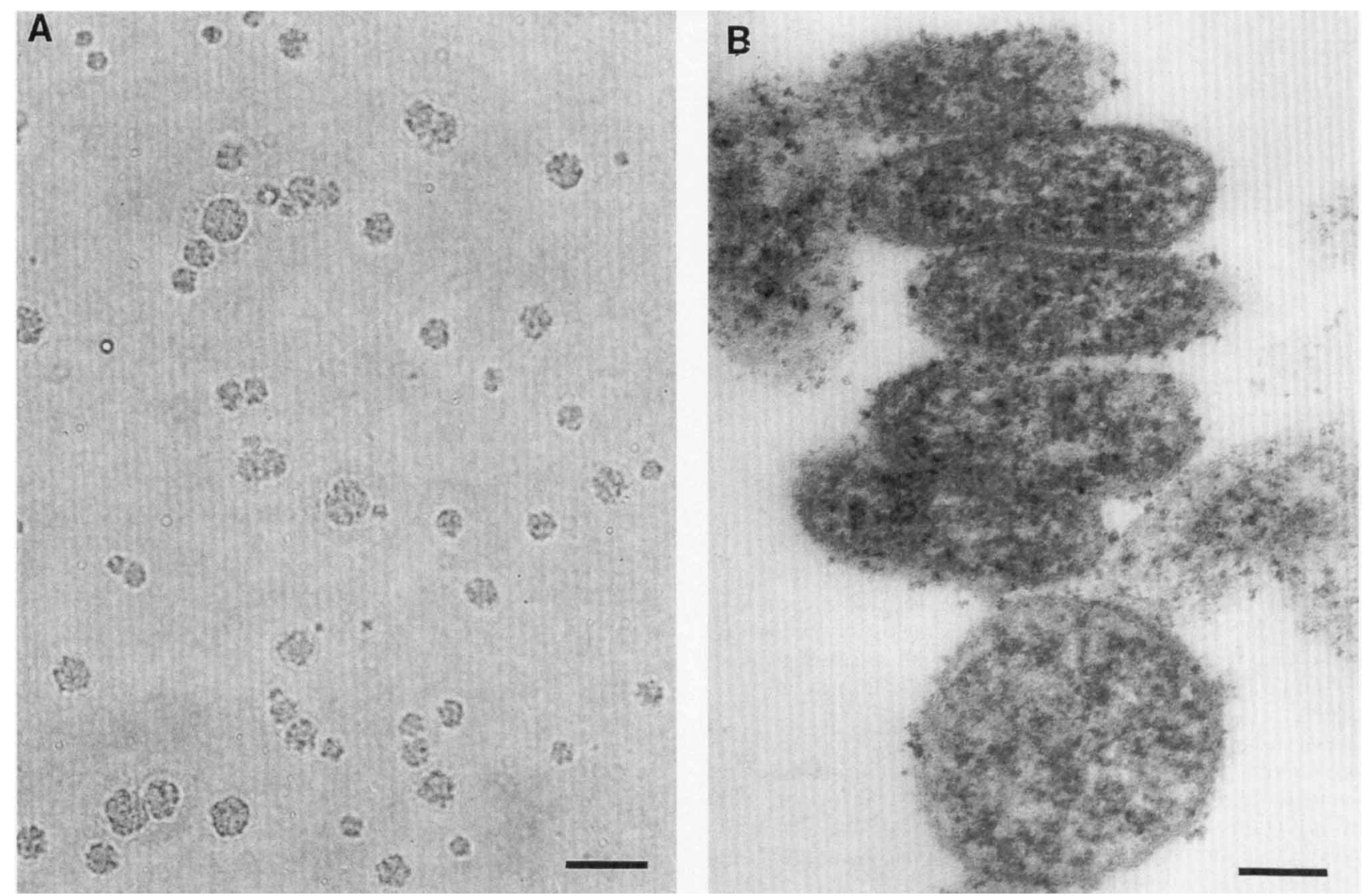

FIG. 1. (A) Typical fried-egg morphology of colonies of elephant mycoplasma strain $\mathrm{E} 42^{\mathrm{T}}$ on agar medium after incubation under aerobic conditions for 2 days. $\mathrm{Bar}=50 \mu \mathrm{m}$. (B) Electron micrograph of an ultrathin section of elephant mycoplasma strain E42 ${ }^{\mathrm{T}}$, showing the absence of a cell wall and the presence of a trilaminar membrane. Bar $=1 \mu \mathrm{m}$.

Gram technique. Ultrathin sections revealed the trilaminar structure of the cell membrane and the absence of a cell wall (Fig. 1B). The cells of the two strains investigated appeared to be mainly coccoid or round. No motility was observed when living strain $E 42^{\mathrm{T}}$ and E73 cells were examined by dark-field microscopy.

Filtration characteristics. Filtration of a broth culture of strain $\mathrm{E} 42^{\mathrm{T}}$ reduced the viable count from $9.0 \times 10^{8} \mathrm{CFU} / \mathrm{ml}$ in the original dilution to $5.2 \times 10^{5} \mathrm{CFU} / \mathrm{ml}$ in the $300-\mathrm{nm}$ pore-size membrane filtrate and to $2.0 \times 10^{3} \mathrm{CFU} / \mathrm{ml}$ in the 220-nm-pore-size membrane filtrate.

Reversion studies. Low passages of strains $E 42^{\mathrm{T}}$ and $\mathrm{E} 73$ were tested for reversion to bacterial forms. No reversion was observed after serial subcultivation in broth or on agar medium lacking bacterial inhibitors.

Sterol requirement. Strains E42 ${ }^{\mathrm{T}}$ and E73 required cholesterol for growth. These organisms could not be cultured on medium without cholesterol, but they grew and were passaged on medium containing $5 \mu \mathrm{g}$ of cholesterol per $\mathrm{ml}$. They were susceptible to digitonin and sodium polyanethol sulfonate, with zones of growth inhibition of 10 and $5 \mathrm{~mm}$, respectively; under these conditions growth was semiconfluent.

Biochemical tests. The biochemical activities of strains $\mathrm{E} 42^{\mathrm{T}}$ and E73 were identical and are summarized in Table 2. Both strains lysed chick, guinea pig, and sheep erythrocytes but did not adsorb these cells.

DNA base composition. The $\mathrm{G}+\mathrm{C}$ content of strain $\mathrm{E} 42^{\mathrm{T}}$ DNA was determined from its buoyant density in cesium chloride to be $24.0 \mathrm{~mol} \%$.
Serological investigations. Strains $E 42^{\mathrm{T}}$ and $\mathrm{E} 73$ reacted identically in growth inhibition tests, metabolism inhibition tests, indirect immunofluorescence tests, and immunobinding assays, indicating that they belong to the same species. In growth inhibition tests we observed reactions between strain $\mathrm{E}^{\mathrm{T}} \mathrm{T}^{\mathrm{T}}$ and antisera against Mycoplasma mobile $163 \mathrm{~K}^{\mathrm{T}}(5-\mathrm{mm}$ clear inhibition zone), Mycoplasma equigenitalium $\mathrm{T} 37^{\mathrm{T}}$ (1.5-mm reduced growth), Mycoplasma genitalium G37 ${ }^{\mathrm{T}}$ (2-mm reduced growth), and Mycoplasma leocaptivus $3 \mathrm{~L} 2^{\mathrm{T}}$ (1-mm reduced growth). In indirect immunofluorescence tests strain $\mathrm{E} 42^{\mathrm{T}}$ showed a moderate reaction with antiserum against $M$. mobile $163 \mathrm{~K}^{\mathrm{T}}$ and very weak reactions with antisera against Mycoplasma citelli RG-2C ${ }^{\mathbf{T}}$, Mycoplasma cynos $\mathrm{H} 831^{\mathrm{T}}$,

TABLE 2. Biochemical properties of strains $E 42^{\mathbf{T}}$ and $\mathrm{E} 73$

\begin{tabular}{lcc}
\hline \multicolumn{1}{c}{ Characteristic } & Strain E42 & Strain E73 \\
\hline $\begin{array}{l}\text { Fermentation of glucose, fructose, maltose, } \\
\quad \text { mannose, and sucrose }\end{array}$ & + & + \\
Hydrolysis of arginine & - & - \\
Hydrolysis of urea & - & - \\
Phosphatase activity & - & - \\
Reduction of tetrazolium chloride & - & - \\
Reduction of potassium tellurite & - & - \\
Film and spot production & + & + \\
Hydrolysis of esculin & - & - \\
Reduction of methylene blue & - & - \\
Reduction of resazurin & + & + \\
\hline
\end{tabular}


A

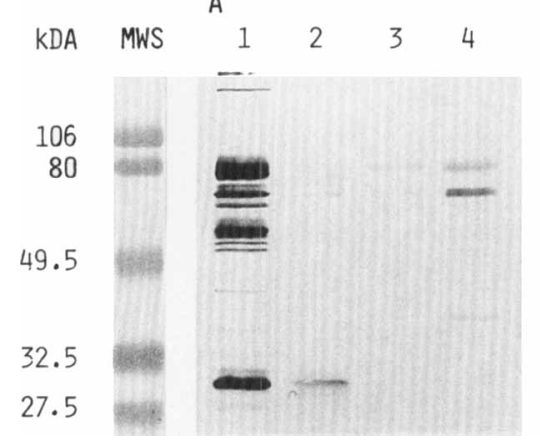

B

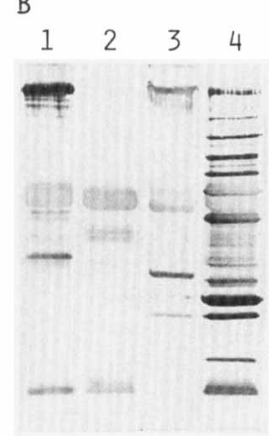

FIG. 2. Western blot analysis of $M$. mobile $163 \mathrm{~K}^{\mathrm{T}}$ (lanes 1$), M$. genitalium $\mathrm{G} 37^{\mathrm{T}}$ (lanes 2), M. equigenitalium $\mathrm{T} 37^{\mathrm{T}}$ (lanes 3), and strain E42 ${ }^{\mathrm{T}}$ (lanes 4) with antisera against $M$. mobile $163 \mathrm{~K}^{\mathrm{T}}(\mathrm{A})$ and strain $\mathrm{E} 42^{\mathrm{T}}(\mathrm{B})$. The protein patterns are quite different. Lane MWS contained molecular weight standards.

M. leocaptivus $3 \mathrm{~L} 2^{\mathrm{T}}$, Mycoplasma mycoides subsp. capri $\mathrm{PG} 3^{\mathrm{T}}$, and Mycoplasma ovipneumoniae $\mathrm{Y}^{\mathrm{T}} 8^{\mathrm{T}}$. No positive reactions were observed between strain $\mathrm{E} 42^{\mathrm{T}}$ and these antisera in metabolism inhibition tests and immunobinding assays and in the reverse tests (i.e., the tests performed with antisera against $\mathrm{E} 42^{\mathrm{T}}$ and $\mathrm{E} 73$ and the type strains of the different mycoplasma species).

Western blotting. M. mobile $163 \mathrm{~K}^{\mathrm{T}}$, M. genitalium $\mathrm{G} 37^{\mathrm{T}}, M$. equigenitalium $\mathrm{T} 37^{\mathrm{T}}$, and strain $\mathrm{E} 42^{\mathrm{T}}$ produced quite different protein patterns in a Western blot analysis performed with antisera against $M$. mobile $163 \mathrm{~K}^{\mathrm{T}}$ and strain $\mathrm{E} 42^{\mathrm{T}}$. The reactions of these four strains with antisera against strain $\mathrm{E} 42^{\mathrm{T}}$ and M. mobile $163 \mathrm{~K}^{\mathrm{T}}$ are shown in Fig. 2 .

Pathogenicity. The mycoplasmas described in this paper were isolated from the genital tracts of female elephants with arthritis. They were not detected in the genital tracts of male elephants and were not found in the respiratory tracts of the elephants. Both female and male elephants had complementfixing antibodies against the mycoplasmas which we isolated, as well as rheumatoid factor activity (4). Whether the mycoplasmas had anything to do with the arthritis that the elephants had is an open question.

Taxonomic assignment. The properties described above for strains $E 42^{\mathrm{T}}$ and E73 fulfill the criteria $(21,22)$ for species descriptions of members of the class Mollicutes. A cell wall is absent, and the cells can be filtered through 220- and 300-nmpore-size membranes, fail to revert to walled bacteria when they are grown in antibiotic-free media, have low $\mathrm{G}+\mathrm{C}$ contents, are resistant to penicillin, and produce typical fried-egg colonies on solid media. The growth requirement for sterol or serum, in conjunction with the lack of helicity, places these organisms in the order Mycoplasmatales and the family Mycoplasmataceae. The inability of the strains to hydrolyze urea mandates assignment to the genus Mycoplasma.

Strains E42 ${ }^{\mathrm{T}}$ and E73 belong to the same species as they have identical biological characteristics and identical serological properties. The lack of serological relatedness of these two strains to other Mollicutes species demonstrates that they represent a previously unrecognized species, for which the name Mycoplasma elephantis is proposed. The taxonomic description below summarizes the properties of this new species.

Description of Mycoplasma elephantis sp. nov. Mycoplasma elephantis (e. le. phan' tis. L. n. elephas, elephant; L. gen. n. elephantis, of the elephant). Cells lack true cell walls and are coccoid or round. Colonies on solid medium usually have a typical fried-egg appearance. Chemoorganotroph. Ferments glucose, fructose, maltose, mannose, and sucrose. Arginine, esculin, and urea are not hydrolyzed. Does not reduce methylene blue, tetrazolium chloride, and potassium tellurite. Produces films and spots on egg yolk agar. Does not possess phosphatase activity. Reduces resazurin. Lyses avian, ovine, and guinea pig erythrocytes. Does not adsorb erythrocytes. Cholesterol or serum is required for growth. The optimum growth temperature is $37^{\circ} \mathrm{C}$. The $\mathrm{G}+\mathrm{C}$ content of the DNA is $24.0 \mathrm{~mol} \%$. Isolated from the genital tracts of female elephants with arthritic symptoms. Pathogenicity has not been proved. The type strain is strain E42 (= ATCC 51980).

\section{ACKNOWLEDGMENTS}

We thank D. L. Rose and J. G. Tully for their efforts in the serological analysis of strain $\mathrm{E} 42^{\mathrm{T}}$, G. A. Stalley for determining the DNA base composition, the T. McP. Brown Arthritis Institute, Arlington, $\mathrm{Va}$., for providing the lyophilized cultures of strains $\mathrm{E} 42^{\mathrm{T}}$ and $\mathrm{E} 73$, and all of the workers who provided mycoplasma strains and antisera.

\section{REFERENCES}

1. Aluotto, B. B., R. G. Wittler, C. O. Williams, and J. E. Faber. 1970. Standardized bacteriologic techniques for the characterization of Mycoplasma species. Int. J. Syst. Bacteriol. 20:35-58.

2. Barber, T. L., and J. Fabricant. 1971. Identification of Mycoplasmatales: characterization procedures. Appl. Microbiol. 21:600-605.

3. Clark, H. W., J. S. Bailey, D. C. Laughlin, and T. M. Brown. 1978. Isolation of mycoplasma from the genital tracts of elephants. Zentralbl. Bakteriol. Parasitenkd. Infektionskr. Hyg. Abt. 1 Orig. 241:262.

4. Clark, H. W., D. C. Laughlin, J. S. Bailey, and T. M. Brown. 1980. Mycoplasma species and arthritis in elephants. J. Zoo Anim. Med. 11:3-15.

5. Clyde, W. A., Jr. 1964. Mycoplasma species identification based upon growth inhibition by specific antisera. J. Immunol. 92:958-965.

6. Del Giudice, R. A., F. Robillard, and T. R. Carski. 1967. Immunofluorescence identification of mycoplasma on agar by use of incident illumination. J. Bacteriol. 93:1205-1209.

7. Edward, D. G. ff. 1971. Determination of sterol requirement for Mycoplasmatales. J. Gen. Microbiol, 69:205-210.

8. Freundt, E. A., B. E. Andrews, H. Erno, M. Kunze, and F. T. Black. 1973. The sensitivity of Mycoplasmatales to sodium-polyanethol sulfonate and digitonin. Zentralbl. Bakteriol. Parasitenkd. Infektionskr. Hyg. Abt. 1 Orig. Reihe A 225:104-112.

9. Gross-Bellard, M. J., P. Oudet, and P. Chambon. 1973. Isolation of high molecular weight DNA from mammalian cells. Eur. J. Biochem. 36:32-38.

10. Hill, A. C. 1971. Mycoplasma caviae, a new species. J. Gen. Microbiol. 65:109-113.

11. Hill, A. C. 1977 . The metabolic inhibition test for mycoplasmas based on phosphatase production. J. Hyg. 79:391-393.

12. Kirchhoff, H., P. Beyene, M. Fischer, J. Flossdorf, J. Heitmann, B. Khattab, D. Lopatta, R. Rosengarten, G. Seidel, and C. Yousef. 1987. Mycoplasma mobile sp. nov., a new species from fish. Int. J. Syst. Bacteriol. 37:192-197.

13. Kotani, H., and G. J. McGarrity. 1985. Rapid and simple identification of mycoplasmas by immunobinding. J. Immunol. Methods 85:257-267.

14. Manchee, R. J., and D. Taylor-Robinson. 1968. Haemadsorption and haemagglutination by mycoplasmas. J. Gen. Microbiol. 50:465-478.

15. Morton, H. E., and R. J. Roberts. 1967. Production of anti-mycoplasma (PPLO) antibodies in rabbits. Proc. Soc. Exp. Biol. Med. 125:538-543.

16. Polak-Vogelzang, A. A., R. Hagenaars, and S. Nagel. 1978. Evaluation of an indirect immunoperoxidase test for identification of Acholeplasma and $M y$ coplasma. J. Gen. Microbiol. 106:241-249.

17. Purcell, R. H., D. Taylor-Robinson, D. C. Wong, and R. M. Chanock. 1966. A color test for the measurement of antibody to the non-acid-forming human mycoplasma species. Am. J. Epidemiol. 84:51-66.

18. Razin, S., and J. G. Tully. 1970. Cholesterol requirement of mycoplasmas. J. Bacteriol. 92:6-12.

19. Rosengarten, R., A. Behrens, A. Stetefeld, M. Heller, M. Ahrens, K. Sachse, D. Yogev, and H. Kirchhoff. 1994. Antigen heterogeneity among isolates of Mycoplasma bovis is generated by high-frequency variation of diverse membrane surface proteins. Infect. Immun. 62:5066-5074.

20. Schildkraut, C. L., J. Marmur, and P. Doty. 1962. Determination of the base composition of deoxyribonucleic acid from its buoyant density in $\mathrm{CsCl}$. J. Mol. Biol. 4:430-443.

21. Subcommittee on the Taxonomy of Mollicutes of the International Committee on Systematic Bacteriology. 1995. Revised minimum standards for description of new species of the class Mollicutes (division Tenericutes). Int. J. Syst. Bacteriol. 45;605-612. 
22. Subcommittee on the Taxonomy of Mollicutes. 1988. Minutes of the interim meeting, 25 and 28 August 1986, Birmingham, Alabama. Int. J. Syst. Bacteriol. 38:226-230.

23. Taylor-Robinson, D., R. H. Purcell, D. C. Wong, and R. M. Chanock. 1966. A colour test for the measurement of antibody to certain mycoplasma species based upon the inhibition of acid production. J. Hyg. 64:91-104.
24. Taylor-Robinson, D., M. H. Williams, and D. A. Haig. 1968. The isolation and comparative biological and physical characteristics of T-mycoplasmas of cattle. J. Gen. Microbiol. 54:33-46.

25. Williams, C. O., and R. G. Wittler. 1971. Hydrolysis of esculin and phosphatase production by members of the order Mycoplasmatales which do not require sterol. Int. J. Syst. Bacteriol. 21:73-77. 